Historic, archived document

Do not assume content reflects current scientific knowledge, policies, or practices. 



\section{A TNEWW FREEZING TECHNIQUE \\ FOR SAMPLING SALMONID REDDS}

\section{William S. Platts}

\section{Vance E. Penton}

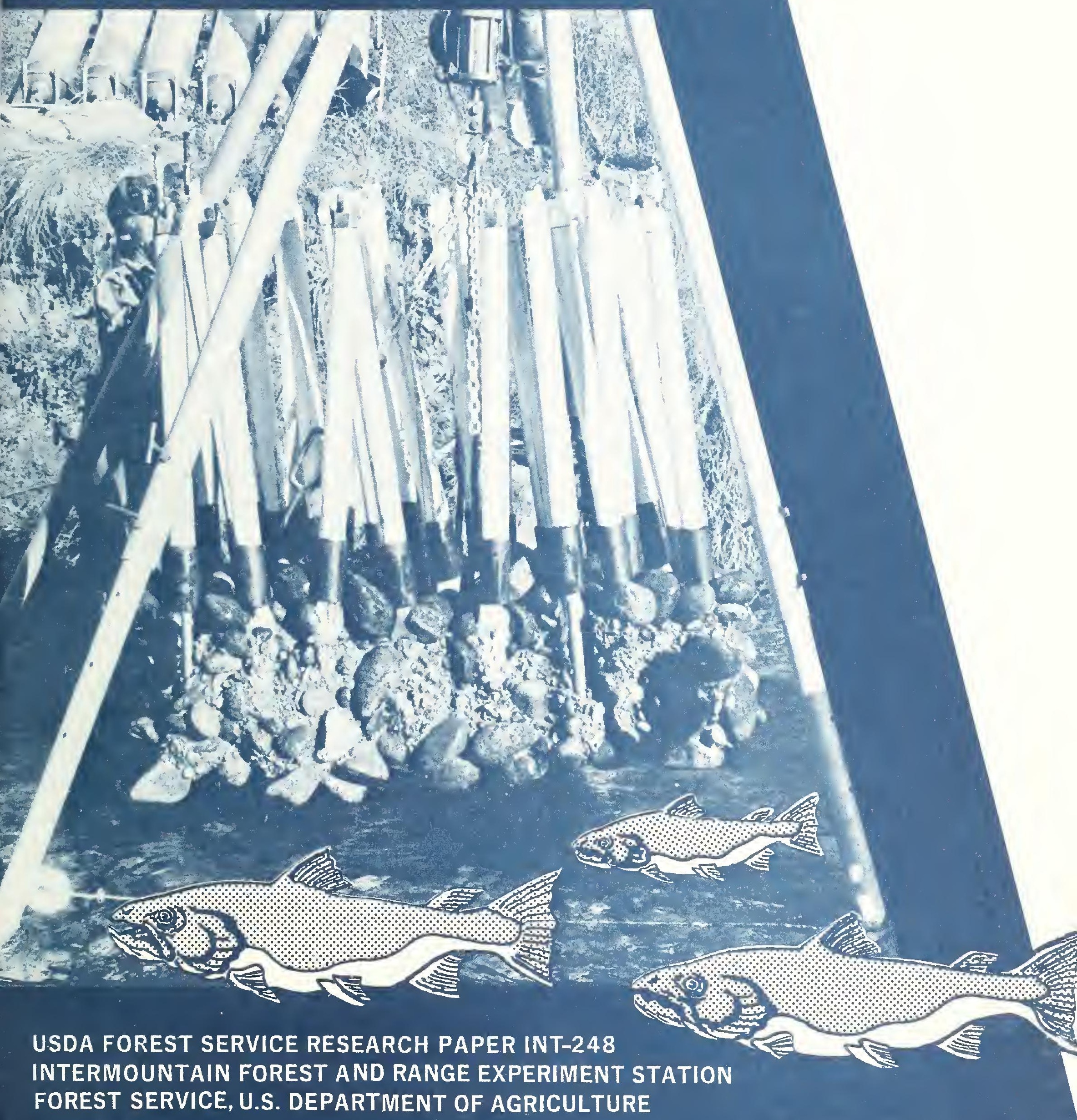





\title{
A NEW FREEZING TECHNIQUE FOR SAMPLING SALMONID REDDS
}

\author{
William S. Platts \\ Vance E. Penton
}

INTERMOUNTAIN FOREST AND RANGE EXPERIMENT STATION

Forest Service

U.S. Department of Agriculture

Ogden, Utah 84401 


\section{THE AUTHORS}

WILIIAM S. PLATTS is a research fishery biologist for the Intermountain Station at Boise, Idaho. He received his B.S. (conservation-education) degree in 1955 from Idaho State University, and his M.S. (fisheries) degree in 1957 and Ph.D. (fisheries) degree in 1972 from Utah State University. From 1957 through 1966 he worked as a regional fishery biologist and supervisor, Enforcement, with the Idaho Fish and Game Department. From 1966 through 1976 he was the Idaho Zone Fishery Biologist for the USDA Forest Service, Intermountain Region, and consultant to the SEAM program. Since 1976 he has worked as a research fishery Biologist, USDA Forest Service, Intermountain Station.

VANCE E. PENTON is an Associate Engineer in the Mechanical Engineering Department at the University of Idaho, Moscow. He received his B.S. (mechanical engineering) degree in 1960 from the University of Idaho and his M.S. (mechanical engineering) degree in 1965 from the University of Idaho. He has worked for the University of Idaho since 1960 as an instructor, research technologist, assistant professor, and associate professor. He was employed as a hydrologic engineer (instrumentation design) for the Agriculture Research Service, Boise, Idaho in the summers of 1964 and 1970. 


\section{RESEARCH SUMMARY}

This report describes a new multiprobe freeze method for determining salmonid redd sediment particle size distribution. This method will collect salmonid eggs and alevins in the redd at any stage of development, any air or water temperature, any stream depth, and determine their horizontal and vertical location. This method allows larger size samples to be collected which can help improve our understanding of embryo and alevin survival rates and causes of their mortality.

This substrate freeze method differs from the past freeze methods that expanded $\mathrm{CO}_{2}$ liquid to atmospheric pressure. This method expands $\mathrm{CO}_{2}$ to a pressure of 78 psia (a boiling liquid - gas medium) which provides a higher heat transfer because of the better control of gas use, higher cooling efficiency, and fewer clogging problems. A field test is described where the ratio of $\mathrm{CO}_{2}$ consumed to redd materials lifted was $0.341 \mathrm{~b} \mathrm{CO}_{2}$ per $1 \mathrm{lb}$ of redd material. A complete step-by-step description of the methodology is given with a listing of parts, materials, and suppliers.

The use of trade, firm, or corporation names in this publication is for the information and convenience of the reader. Such use does not constitute an official endorsement or approval by the U.S. Department of Agriculture of any product or service to the exclusion of others which may be suitable. 


\section{CONTENTS}

INTRODUCTION . . . . . . . . . . . . . . . . . 1

WATER-SUBSTRATE COOLING REQUIREMENTS . . . . . . . . 2

DESCRIPTION OF NEW METHOD . . . . . . . . . . . 4

$\mathrm{CO}_{2}$ Liquid-Gas Phase .. . . . . . . . . . 4

$\mathrm{CO}_{2}$ in the system............. . 4

Probe and Water Flow Shield........ . 6

DESCRIPTION OF EQUIPMENT . . . . . . . . . . 6

Probes and Caps............. 6

$\mathrm{CO}_{2}$ Supply System . . . . . . . . . . . 9

Lifting Apparatus . . . . . . . . . . . . 9

Temperature Equipment. . . . . . . . . . II

Sample Transportation . . . . . . . . . . 11

OPERATION OF EQUIPMENT . . . . . . . . . . . . . . II

Probes and Caps . . . . . . . . . . . . 12

Water Flow Shield, Lifting Hoist, and

Instrumentation . . . . . . . . . . . . 13

FREEZING PROCEDURE . . . . . . . . . . . . . 14

Problems ................. 15

Shut Down Procedure . . . . . . . . . . 15

MAINTENANCE`AND SAFETY . . . . . . . . . . . 16

DISCUSSION . . . . . . . . . . . . . . 16

PUBLICATIONS CITED . . . . . . . . . . . . . 18

APPENDIX A. . . . . . . . . . . . . . . . . . 19

Equipment List and Supplier. . . . . . . . 19

APPENDIX B. . . . . . . . . . . . . . . . 21

Cost of Equipment and $\mathrm{CO}_{2}$. . . . . . . . 2I 


\section{INTRODUCTION}

Large increases in sediment loads in stream channels can create intolerable changes to material size composition of salmonid spawning areas (Platts and Megahan 1975). The more commonly used methods to detect and determine the magnitude of these intolerable changes are, however, often inadequate.

The metal core tube (McNeil 1964), which is primarily used in Idaho and other areas in the Pacific Northwest, does not determine the vertical and horizontal stratification of the redd sediment particle size distribution. Therefore, this method could be biased in determining the true effects of sediments on embryo and alevin survival. Salmonid embryo and alevin survival rates have usually been estimated by sampling stream channel materials with 6- to 12-inch (152 to $305 \mathrm{~mm}$ ) tube core samplers. The substrate particle size distribution of the samples collected is then used to estimate potential survival rates. These estimates may not be accurate because the sediment particle size is (1) limited to the size the coring tube can encase, (2) the sample is completely mixed so no interpretation can be made of vertical and horizontal differences in particle size distribution, (3) the sampling depth is limited by both water depth and the length of the collector's arm, (4) the core tube can push larger particle sizes out of the collecting area, (5) suspended sediments in the core can be lost, and (6) the individual sample size is limited to the core tube diameter. Therefore, the core samples collected may be biased to certain particle sizes.

This report describes a new freeze sampling method similar to those developed by Walkotten (1976) and Lotspeich and Reid (in press). Walkotten (1976) originally developed the freeze core method to lessen the biases previously discussed in sampling channel sediments. Our recent unpublished work, as well as Ringler's (1970), comparing the tube core sampler with the freeze core sampler, suggests, however, that the single probe method may be biased toward larger size sediment particles. We believe one of the main reasons for this bias is that the freeze probe collects larger size particles on the core perimeter more readily than it collects smaller size particles. The smaller size particles may fall off in a higher weight ratio during core extraction. Lotspeich and Reid (in press) have attempted to solve some. of these problems by using three freeze probes instead of one. Our new method helps eliminate the perimeter bias by allowing a much larger sample to be taken. The previous methods also have a tendency to take uneven amounts of substrate in the vertical direction, thus collecting more sediment at one depth than another. The new system takes a uniform sample.

The new method, as does the methods used by walkotten (1976) and Lotspeich and Reid (in press) allows collection of the eggs and alevins in the redd at any stage of development, will function at any air or water temperature or stream depth, and will determine the horizontal and vertical location of the eggs and alevins. The new system uses $\mathrm{CO}_{2}$ more efficiently and alleviates problems of clogging from dry ice. The method will take a sample of any size that can be lifted and transported and will allow the complete redd or selected parts of the redd to be analyzed in the laboratory in a near natural condition. The method has the potential for improving our estimates of embryo and alevin survival rates and identifying causes of their mortality. 


\section{WATER-SUBSTRATE COOLING REQUIREMENTS}

The actual cooling requirements were estimated for freezing a 24 by 48 by 18 inch $(0.61$ by 1.22 by $0.46 \mathrm{~m})$ substrate sample. The following assumptions were made in calculating the requirements:

a. There is no appreciable water circulation in the sample.

b. The water temperature remains constant at $40^{\circ} \mathrm{F}\left(4.5^{\circ} \mathrm{C}\right)$.

c. The average temperature of the frozen sample is $0^{\circ} \mathrm{F}\left(-18^{\circ} \mathrm{C}\right)$.

d. The average dry sample density is $1151 \mathrm{~b} / \mathrm{ft}^{3}\left(1.85 \mathrm{~g} / \mathrm{cm}^{3}\right)$

(Terzaphi and Peck 1948).

e. The unit density of the solids is $1651 \mathrm{~b} / \mathrm{ft}^{3}\left(2.65 \mathrm{~g} / \mathrm{cm}^{3}\right)$ (Terzaphi and Peck 1948).

f. Two inches $(5 \mathrm{~cm})$ of the periphery of the sample is rock with very little ice or fine sediment because the rock may be frozen to the sample on one side only.

The constants used in calculating the cooling requirements were taken from Baumester (1967).

Specific heat $(\mathrm{Cp})$

$$
\begin{array}{ll}
\mathrm{C}_{\mathrm{p}} \text { water } & =1 \mathrm{Btu} / 1 \mathrm{~b}\left(4.18 \mathrm{~J} / \mathrm{g}^{\circ} \mathrm{K}\right) \\
\mathrm{C}_{\mathrm{p}} \text { ice } & =0.48 \mathrm{Btu} / 1 \mathrm{~b}\left(2.01 \mathrm{~J} / \mathrm{g}^{\circ} \mathrm{K}\right) \\
\mathrm{C}_{\mathrm{p}} \text { rock } & =0.20 \mathrm{Btu} / 1 \mathrm{~b}\left(0.84 \mathrm{~J} / \mathrm{g}^{\circ} \mathrm{K}\right)
\end{array}
$$

Heat of fusion

$$
\text { Water }=144 \mathrm{Btu} / \mathrm{lb}(355 \mathrm{~J} / \mathrm{g})
$$

The approximate percent voids in the sample which are filled with water are determined by the following equation (Terzaphi and Peck 1948):

$$
n=1-\frac{y d}{y s}
$$

where

$$
\begin{aligned}
\mathrm{n} & =\text { percent porosity } \\
\mathrm{yd} & =\text { unit dry weight } \\
\text { ys } & =\text { unit solid weight } \\
\mathrm{n} & =1-(1.85 / 2.65)=0.30 \text { or } 30 \text { percent voids. }
\end{aligned}
$$

Sample weight is calculated as follows:

$$
\begin{aligned}
\text { weight of rock }\left(W_{r}\right) & =(\text { volume of sample) (dry density) } \\
w_{r} & =(2)(4)(1.5)(115) \\
w_{r} & =1,3801 \mathrm{~b} \text { or } 626 \mathrm{~kg}
\end{aligned}
$$


weight of water $\left(W_{W}\right)=$ (volume of sample w/ice) (porosity) (water density)

$$
\begin{array}{ll}
W_{W} & =(24-4)(48-4)(18-2)(0.3)(62.4) / 1,728 \\
W_{W} & =1521 \mathrm{~b} \text { or } 69 \mathrm{~kg}
\end{array}
$$

Calculations for the cooling requirements are shown below:

Cooling water and rock to $0^{\circ} \mathrm{C}$ plus ice:

Water $40^{\circ}$ to $32^{\circ} \mathrm{F}\left(4.5^{\circ}\right.$ to $\left.0^{\circ} \mathrm{C}\right)$

$$
\begin{aligned}
\Delta \mathrm{H} & =\left(W_{W}\right)\left(C_{\mathrm{pw}}\right)(\Delta t) \\
& =(152)(1)(8) \\
& =1,216 \text { Btu or } 1.28 \mathrm{MJ} \\
\Delta \mathrm{H} & =\left(\mathrm{W}_{\mathrm{W}}\right) \text { (heat of fusion) } \\
& =(152)(144) \\
& =21,888 \text { Btu or } 23.1 \mathrm{MJ}
\end{aligned}
$$

Water to ice $\Delta \mathrm{H}=\left(\mathrm{W}_{\mathrm{W}}\right)$ (heat of fusion)

Rock $40^{\circ}$ to $32^{\circ} \mathrm{F}\left(4.5^{\circ}\right.$ to $\left.0^{\circ} \mathrm{C}\right)$

$$
\begin{aligned}
\Delta \mathrm{H} & =\left(\mathrm{W}_{\mathrm{r}}\right)\left(\mathrm{C}_{\mathrm{pr}}\right)(\Delta \mathrm{t}) \\
& =(1,380)(0.2)(8) \\
& =2,208 \text { Btu or } 2.33 \mathrm{MJ}
\end{aligned}
$$

Total to freeze $\quad=25,312$ Btu or $26.7 \mathrm{MJ}$

Cooling ice and rock to $0^{\circ} \mathrm{F}\left(-18^{\circ} \mathrm{C}\right)$ :

Ice $32^{\circ}$ to $0^{\circ} \mathrm{F}\left(0^{\circ}\right.$ to $\left.-18^{\circ} \mathrm{C}\right)$

$$
\begin{aligned}
\Delta \mathrm{H} & =\left(W_{\mathrm{w}}\right)\left(\mathrm{C}_{\mathrm{pi}}\right)(\Delta t) \\
& =(152)(0.48)(32) \\
& =2,335 \text { Btu or } 2.46 \mathrm{MJ}
\end{aligned}
$$

Rock $32^{\circ}$ to $0^{\circ} \mathrm{F}\left(0^{\circ}\right.$ to $\left.-18^{\circ} \mathrm{C}\right)$

$$
\begin{aligned}
\Delta \mathrm{H} & =\left(\mathrm{W}_{\mathrm{r}}\right)\left(\mathrm{C}_{\mathrm{pr}}\right)(\Delta \mathrm{t}) / 1,000 \\
& =(1,380)(0.2)(32) \\
& =8,832 \text { Btu or } 9.3 \mathrm{MJ}
\end{aligned}
$$

Total $32^{\circ}$ to $0^{\circ} \mathrm{F}\left(0^{\circ}\right.$ to $\left.-18^{\circ} \mathrm{C}\right)=11,167$ Btu or $11.76 \mathrm{MJ}$ TOTAL COOLING REQUIREMENT

$40^{\circ}$ to $0^{\circ} \mathrm{F}\left(4.5^{\circ}\right.$ to $\left.-18^{\circ} \mathrm{C}\right) \quad 36,479$ Btu or $38.47 \mathrm{MJ}$ 
The cooling available from liquid $\mathrm{CO}_{2}$ is approximately $80 \mathrm{Btu} / \mathrm{lb}(0.186 \mathrm{MJ} / \mathrm{kg})$ from heat of vaporization and $22 \mathrm{Btu} / 1 \mathrm{~b}(0.051 \mathrm{MJ} / \mathrm{kg})$ from heat absorbed between $-11^{\circ} \mathrm{F}$ and $-0^{\circ} \mathrm{F}\left(-79^{\circ} \mathrm{C}\right.$ and $\left.-18^{\circ} \mathrm{C}\right)$ for a total of $102 \mathrm{Btu} / 1 \mathrm{~b}(0.237 \mathrm{MJ} / \mathrm{kg})$ (Ashrae 1972). The amount of liquid $\mathrm{CO}_{2}$ was calculated, assuming 70 percent efficiency, as follows:

$$
\mathrm{kg} \text { of } \mathrm{CO}_{2}=(36,479)(102)(0.7)=5101 \mathrm{~b} \text { or } 232 \mathrm{~kg}
$$

If the conditions described in the paragraph above could be maintained, then the $\mathrm{CO}_{2}$ consumption per $\mathrm{kg}$ of dry sample would be approximately $0.368 \mathrm{lb} \mathrm{CO}_{2} / 1 \mathrm{~b}$ sample $(0.368 \mathrm{~kg} \mathrm{CO} 2 / \mathrm{kg})$ or about 25 percent of the $\mathrm{CO}_{2}$ necessary in Walkotten's (1976) system.

Three variables can cause large discrepancies in the cooling values calculated above. The first is water temperature. If the water temperature was $59^{\circ} \mathrm{F}\left(15^{\circ} \mathrm{C}\right)$ instead of $40^{\circ} \mathrm{F}\left(4.5^{\circ} \mathrm{C}\right)$, the $\mathrm{CO}_{2}$ required for cooling would increase 22 percent. The second variable affecting the $\mathrm{CO}_{2}$ requirement is the amount of water circulated through the sample area. As an example, a volume flow rate of $1.05 \mathrm{ft} / \mathrm{min}$ $\left(494 \mathrm{~cm}^{3} / \mathrm{s}\right)$, which would be equivalent to a velocity of $0.02 \mathrm{ft} / \mathrm{s}(0.61 \mathrm{~cm} / \mathrm{s})$ through the void area in the sample, could add 28,156 Btu (29.7 MJ) of heat to the sample with a $7.2^{\circ} \mathrm{F}\left(4^{\circ} \mathrm{K}\right)$ temperature change in 1 hour. The above velocity would be about $1 / 100$ of normal stream velocity. If very rapid cooling cannot be achieved within 10 minutes, the surface water circulation needs to be reduced to near zero-if possible. The third variable is the cooling efficiency of the $\mathrm{CO}_{2}$. At least 70 percent of the $\mathrm{CO}_{2}$ cooling capacity should be released into the sample.

\section{DESCRIPTION OF NEW METHOD}

\section{$\mathrm{CO}_{2}$ Liquid-Gas Phase}

The freeze methods used today (Walkotten 1976; Lotspeich and Reid, in press) expand $\mathrm{CO}_{2}$ liquid to atmospheric pressure producing a gas of $-110^{\circ} \mathrm{F}\left(-78^{\circ} \mathrm{C}\right)$. This causes large amounts of solid $\mathrm{CO}_{2}$ (dry ice) to form. Dry ice is a poor heat transfer medium and as it builds up in the probe it decreases the cooling capacity of the expanding $\mathrm{CO}_{2}$. Our new method expands $\mathrm{CO}_{2}$ to a pressure of 78 psia $(540 \mathrm{kPa})$ producing a temperature of $-68^{\circ} \mathrm{F}\left(-55^{\circ} \mathrm{C}\right)$. At this temperature $\mathrm{CO}_{2}^{\prime}$ is a boiling liquid-gas medium which provides a much higher rate of heat transfer than dry ice. Initially, the heat transfer rate is less because of the higher temperature $\left(-68^{\circ} \mathrm{F}\right.$ or $\left.-55^{\circ} \mathrm{C}\right)$ of the liquid-gas rather than gas at atmospheric pressure $\left(-110^{\circ} \mathrm{F}\right.$ or $\left.-78^{\circ} \mathrm{C}\right)$. Liquid $\mathrm{CO}_{2}$ allows for better gas control, higher cooling efficiency, and fewer clogged probes and lines by dry ice.

\section{$\mathrm{CO}_{2}$ in the System}

A schematic of the system and probe layout is provided in figures 1 and 2 . The tanks containing the $\mathrm{CO}_{2}$ are stationed on the bank. The $\mathrm{CO}_{2}$ in these tanks is maintained under a pressure of 500 to 850 psia ( 3.45 to $5.85 \mathrm{MPa})$ depending on ambient temperature. The tanks release $\mathrm{CO}_{2}$ through high pressure hoses to a distribution manifold where it is filtered. The $\mathrm{CO}_{2}$ then flows through opened throttle valves attached to each of the four rows of probes and enters the first probe in each row. These probes rapidly fill with $\mathrm{CO}_{2}$ liquid and the overflow travels into the next probe in each row. This procedure is repeated until all probes are filled. The excess $\mathrm{CO}_{2}$ leaves the last probe through an adjustable relief valve. The liquid is then throttled to a pressure of 79 to 84 psia $(540$ to $580 \mathrm{kPa})$ providing a temperature of $-68^{\circ} \mathrm{F}\left(-55^{\circ} \mathrm{C}\right)$. By maintaining $\mathrm{CO}_{2}$ in liquid form all the available heat of vaporization for cooling the sample is used. This represents nearly 80 percent of the cooling capacity of the $\mathrm{CO}_{2}$. 


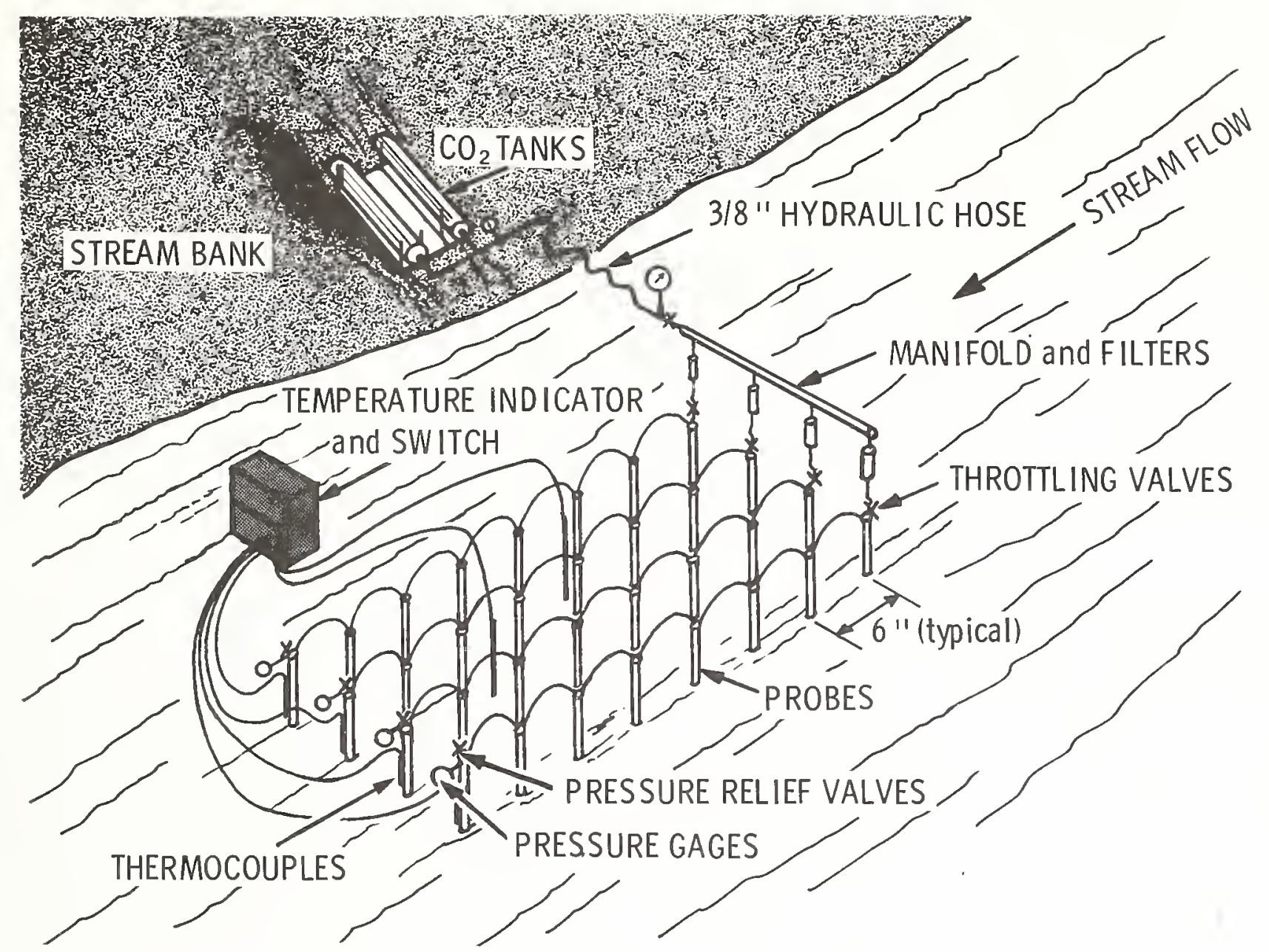

Figure 1.--Layout of sediment freeze probes and $\mathrm{CO}_{2}$ gas 1 ine distribution.

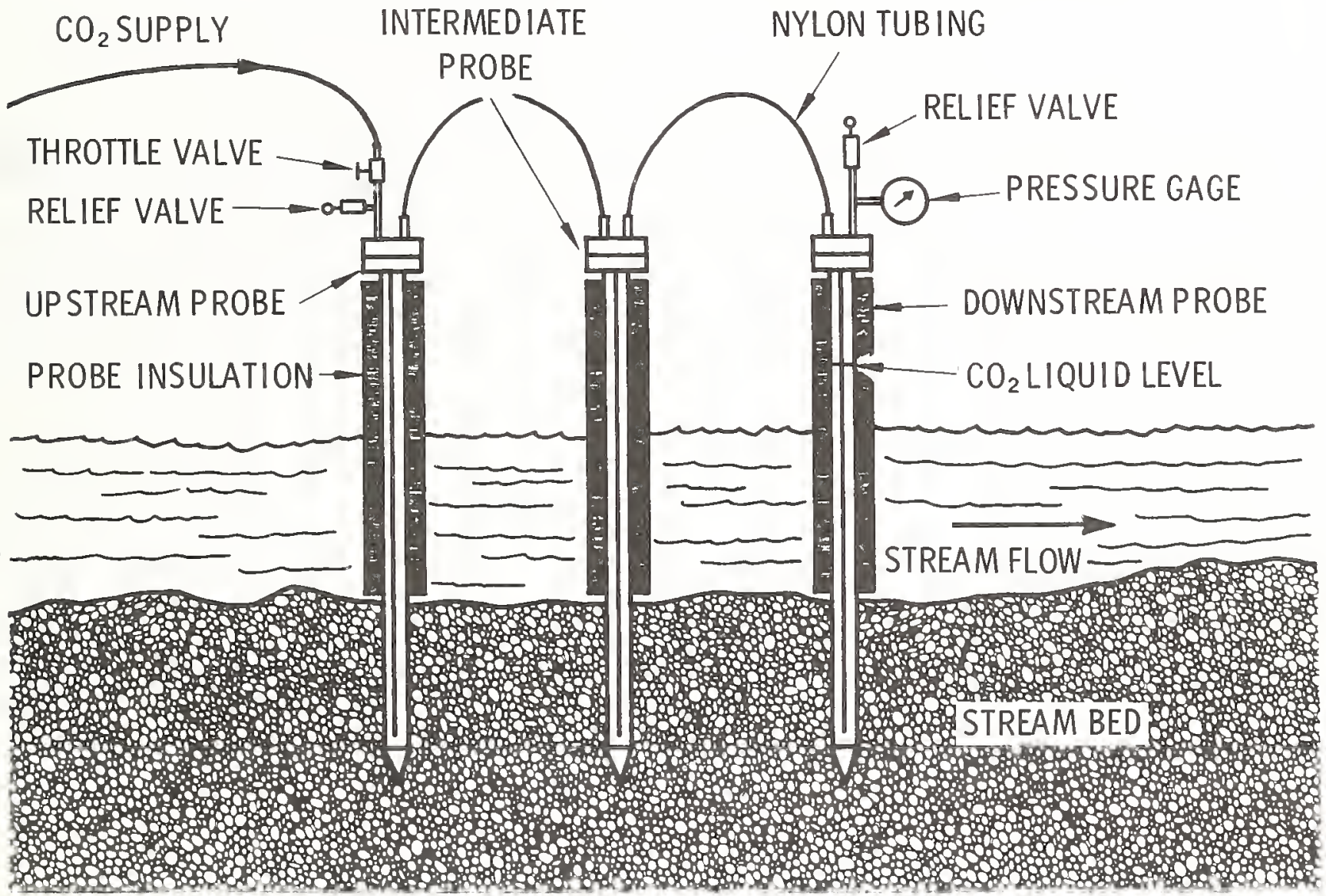

Figure 2.--Drawing of freezing probe schematic under operation. 
A pressure gage located on the last probe in each row monitors the $\mathrm{CO}_{2}$ pressure. The throttle and relief valves are adjusted to maintain the desired pressure in the system and minimize the loss of $\mathrm{CO}_{2}$ through the relief valve. A second relief valve is positioned on the first probe to relieve excessive pressure (over 100 psi) if blockage should occur in intermediate probes. Such a blockage could allow full tank pressure to be applied to the probes ahead of the blockage.

Maximum efficiency in this system requires the liquid and gas $\mathrm{CO}_{2}$ to be held at a uniform pressure and therefore, temperature, while it continually circulates in the tubes and probes providing the turbulence necessary for efficient heat transfer. Also, the probes are insulated above the stream channel to reduce cooling losses to water and air. A uniform probe wall temperature is maintained because the $\mathrm{CO}_{2}$ is at a constant temperature for a given operating pressure.

\section{Probe and Water Flow Shield}

The probes are driven into the riverbed to the desired freezing depth exposing the $\mathrm{CO}_{2}$ cooled probe wall directly to the substrate. The probes are arranged in four rows of eight probes each and spaced 6 inches $(15.2 \mathrm{~cm})$ apart so that an area 2 by $4 \mathrm{ft}(0.61$ by $1.22 \mathrm{~m})$ will be frozen. This provides good control of $\mathrm{CO}_{2}$ consumption but requires 1 to $1-1 / 2$ hours freezing time. The water circulation must be reduced to low flows for complete freezing to take place. To reduce water circulation, a metal shield and canvas was worked into the streambed around the probes. If high water temperatures become a problem they can be overcome by using more $\mathrm{CO}_{2}$ and extending the time of $\mathrm{CO}_{2}$ circulation.

\section{DESCRIPTION OF EQUIPMENT}

\section{Probes and Caps}

The probe and cap construction is shown in figures 3 and 4 . The brass flanges were wetted over the entire joint area while being soldered to the top of the probe. This required pretinning the inside of the flange and the outside of the probe. The probe parts not used directly for freezing were insulated with Ce11-0Flex pipe and insulation. DWV pipe was installed loosely over the probe and held in place with spacers. With the bottom cap removed, insulation was poured between the pipe and probe.

Three different probe cap configurations were used depending on the location of the probes (fig. 5). The basic cap consists of a piece of brass hex machined to the dimensions shown in figure 4. The copper tube is on the inlet side of the cap. The caps for the upstream probe in each row have a $1 / 4$-inch ( $6.35 \mathrm{~mm})$ hydraulic swivel fitting, a throttle valve, and a relief valve connected to the inlet side of the cap. The downstream cap in each row has 100 psia $(0.689 \mathrm{MPa})$ gage and a relief valve on the outlet side of the cap. All other cap connections have tube fittings as indicated. The probes are connected with flexible nylon tubing rated for 700 psia $(4.83 \mathrm{MPa})$. The downstream probe in each row has a $1 / 8$-inch $(3.3 \mathrm{~mm})$ stainless steel clad thermocouple mounted on it to record probe wall temperatures. The thermocouple is equipped with a standard plug near the top of the probe. 


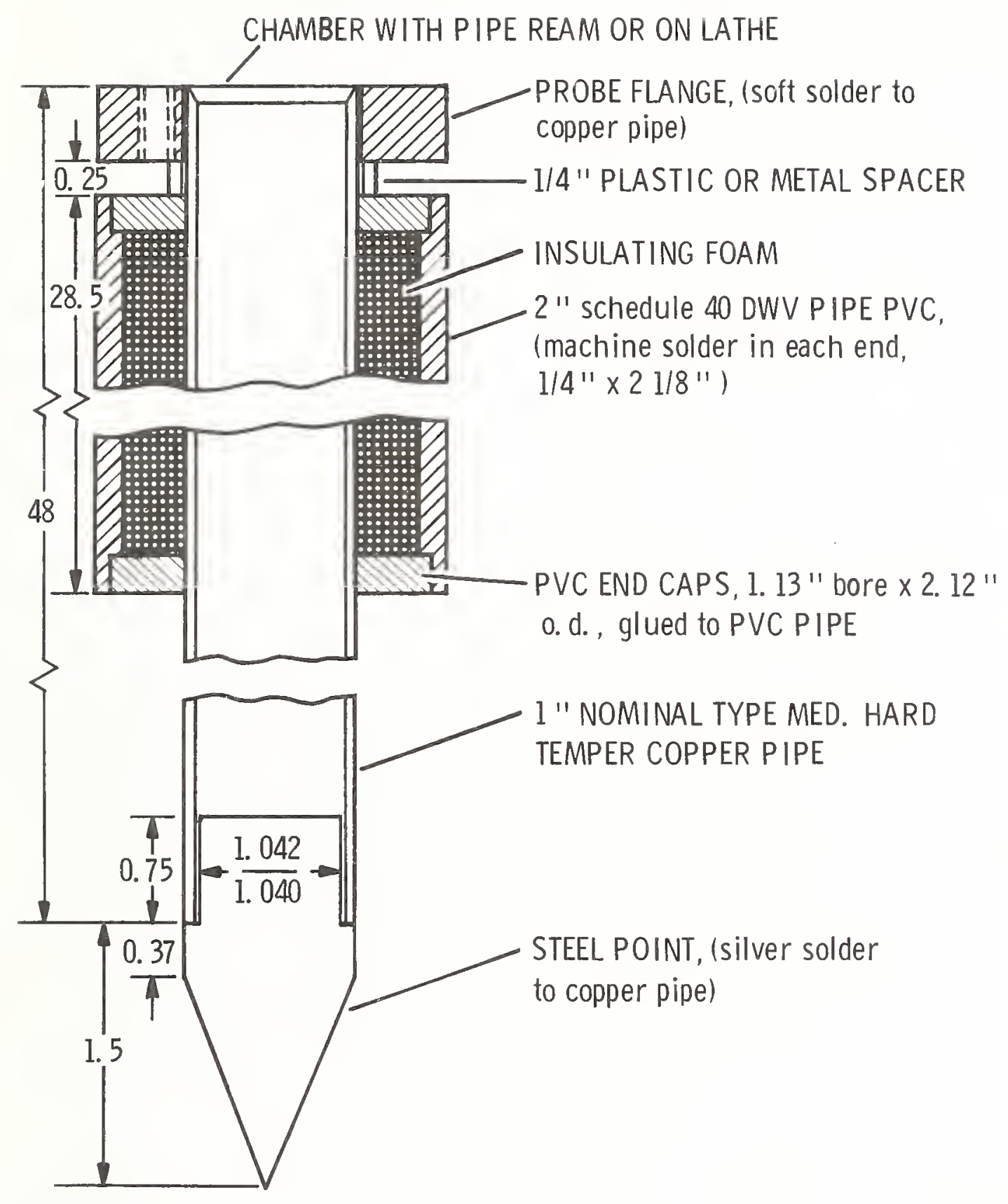

Figure 3.--Details of freezing probe. 


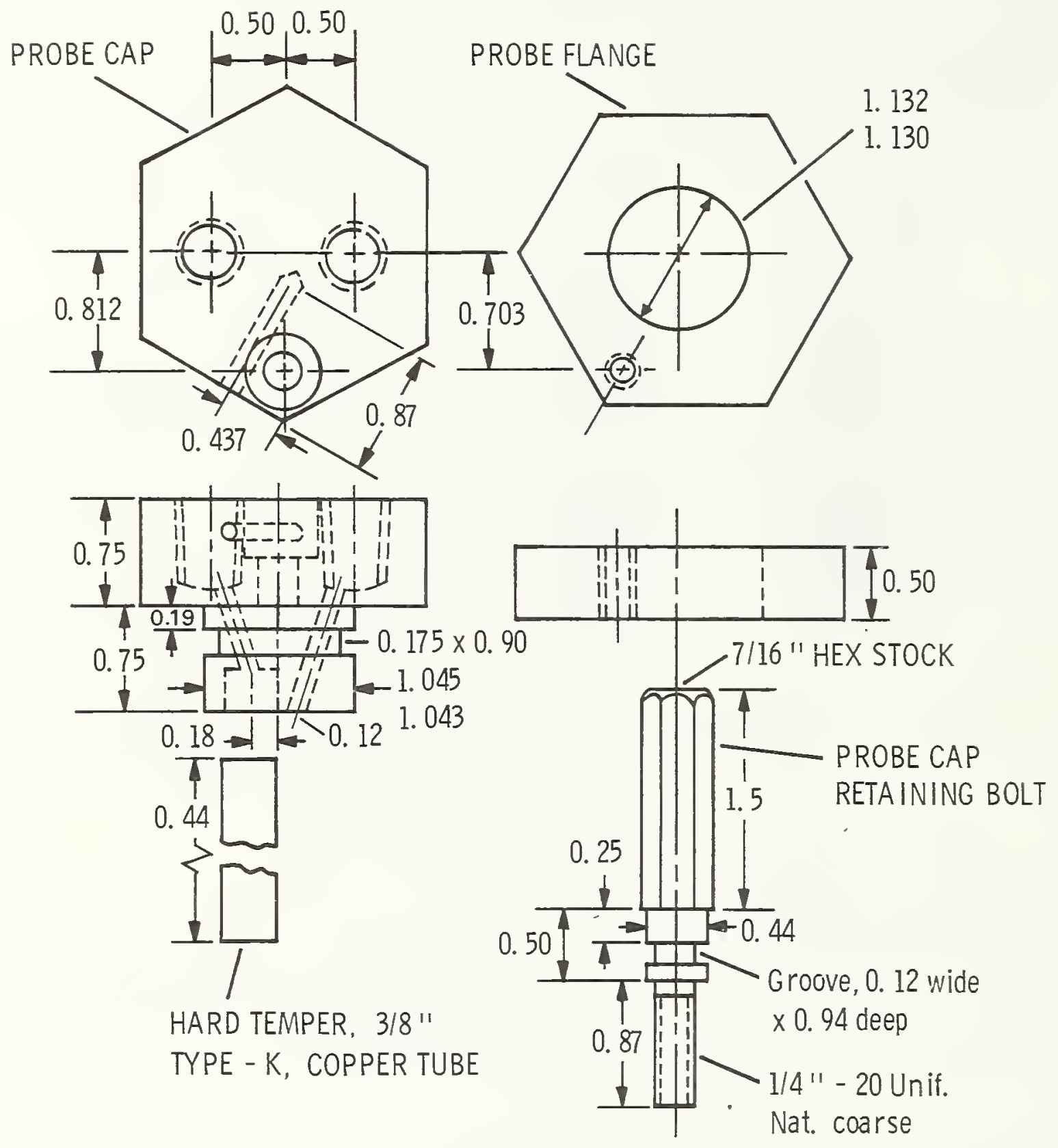

Full Scale: (measurements in inches)

Note: Copper tube is soldered to probe cap.

Probe cap and flange are made from brass

and retaining bolt is made from mild steel.

Figure 4.--Details of probe cap and flange. 
INLET PRESSURE RELIEF (100 psi)
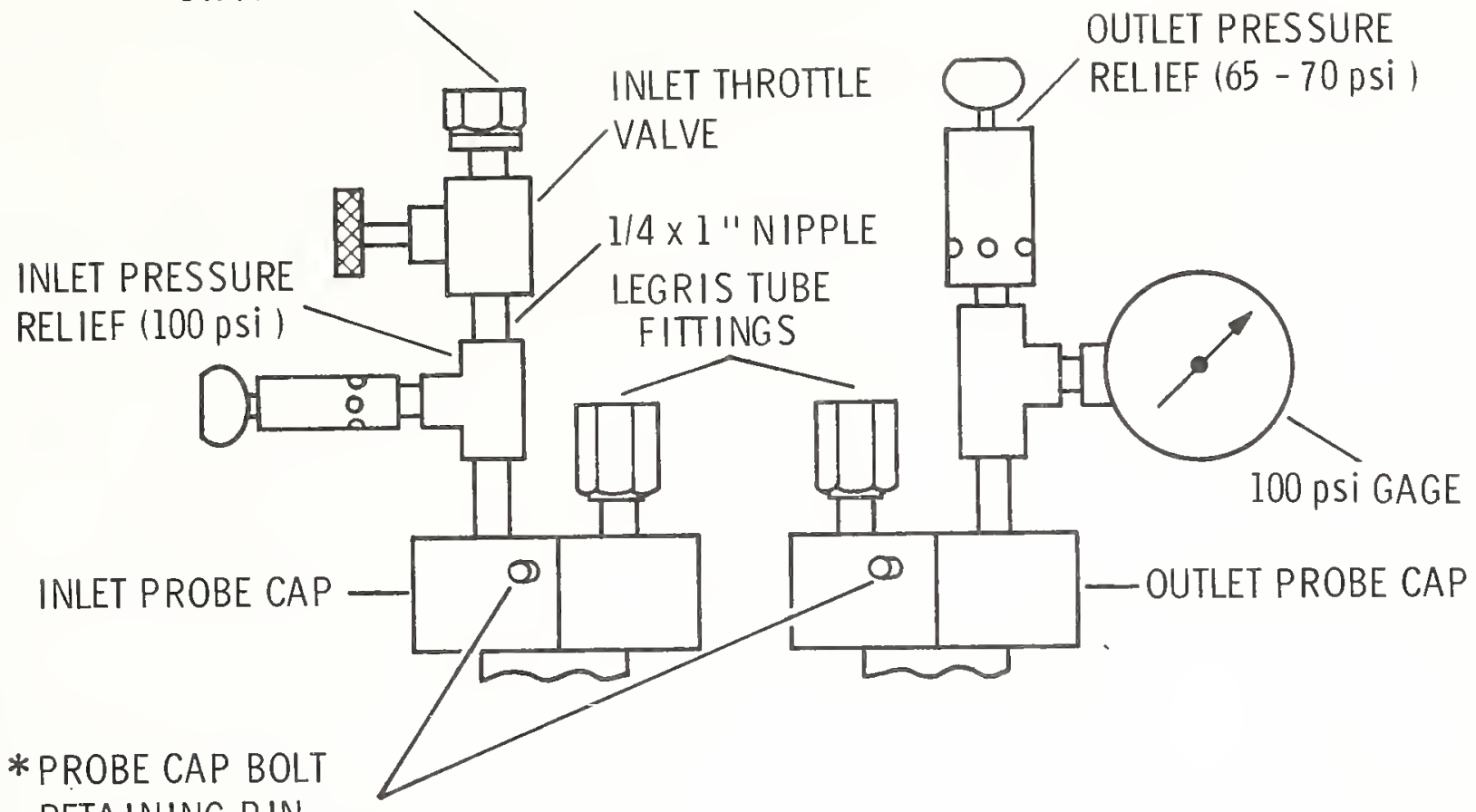
RETAINING PIN, (NEAR INLET CONNECTIONS) LEGRIS TUBE FITIINGS

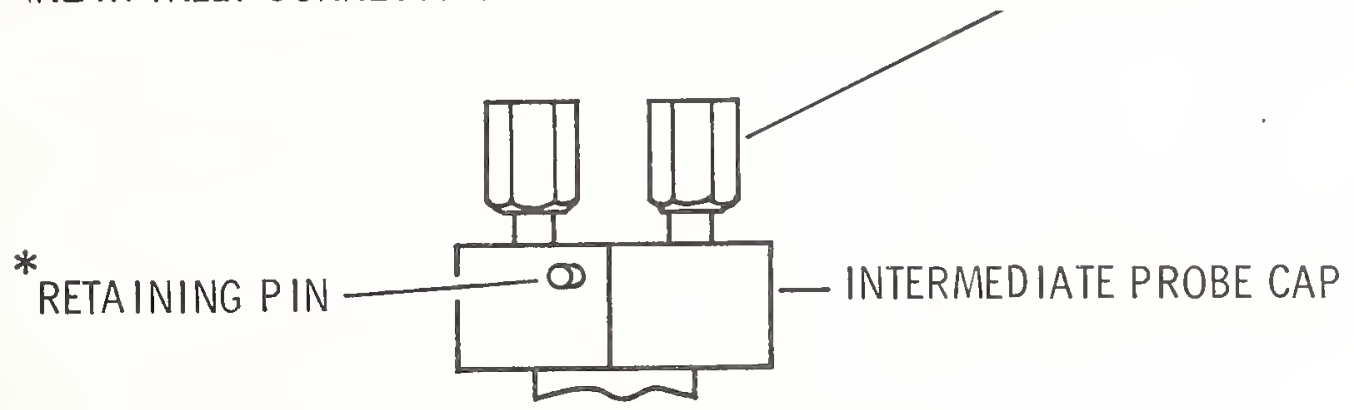

Figure 5.--Probe cap fittings.

\section{$\mathrm{CO}_{2}$ Supply System}

The $\mathrm{CO}_{2}$ tanks are held in tilting frames so the outlet is lower than the rest of the tank, thus eliminating the need for siphons. The tanks are connected with $\mathrm{T}$ fittings and 12 -inch $(30.5 \mathrm{~cm})$ lengths of $1 / 4-i n c h(6.3 \mathrm{~mm})$ hydraulic hose. A gage measuring at least 1,000 psia $(6.89 \mathrm{MPa})$ is mounted between the tanks and the main supply hose. The main supply hose is SAE 100R3 3/8-inch I.D. hydraulic hose. A shut-off valve and the measuring gage are mounted on the end of the hose. The hose and valve connect to a manifold which distributes the $\mathrm{CO}_{2}$ through four wire screen filters to an 18-inch $(45 \mathrm{~cm})$ SAE 100R3 hydraulic hose connected to the probe throttle valves. All hoses and fittings are exposed to full tank pressure during operation. The gage readings determine if the $\mathrm{CO}_{2}$ is flowing normally.

\section{Lifting Apparatus}

Figure 6 describes the ice anchors used to lift the sample. Figure 7 shows the aluminum tripod lifting frame extracting the sample. The telescoping legs are adjustable to fit variation in streambed contour (fig. 7 and 8). The frame lifting capacity is $5,0001 \mathrm{~b}(2268 \mathrm{~kg})$. 


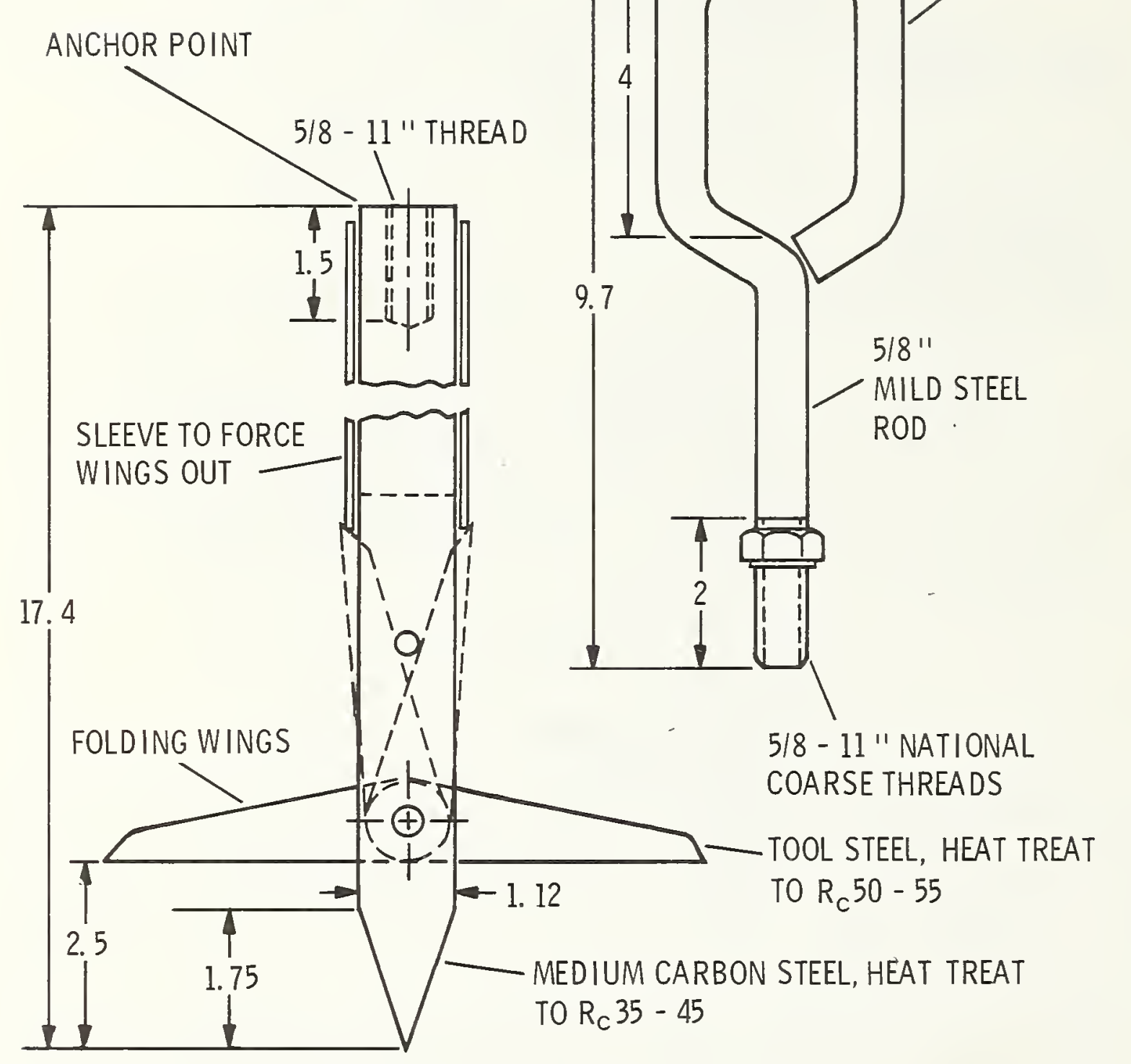

Figure 6.--Details of anchors. 


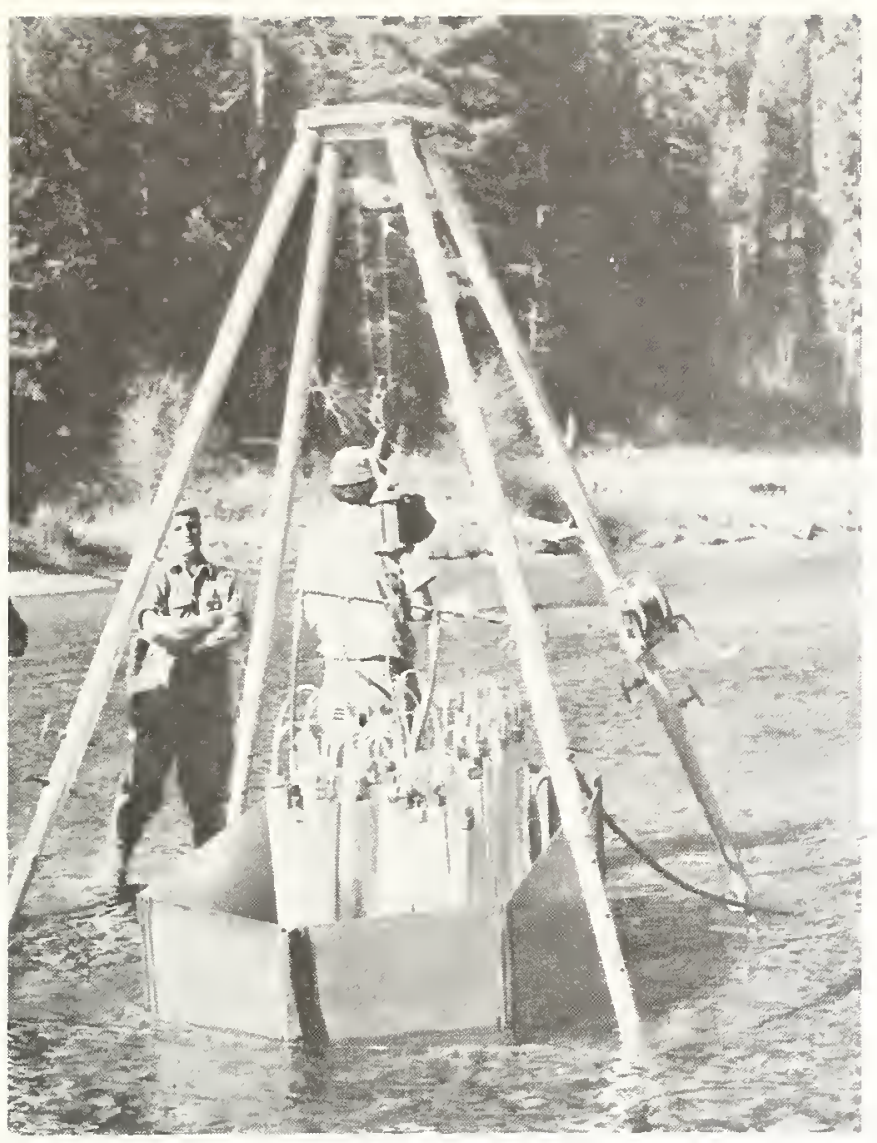

Figure 7.--Hoist used to lift substrate sample.

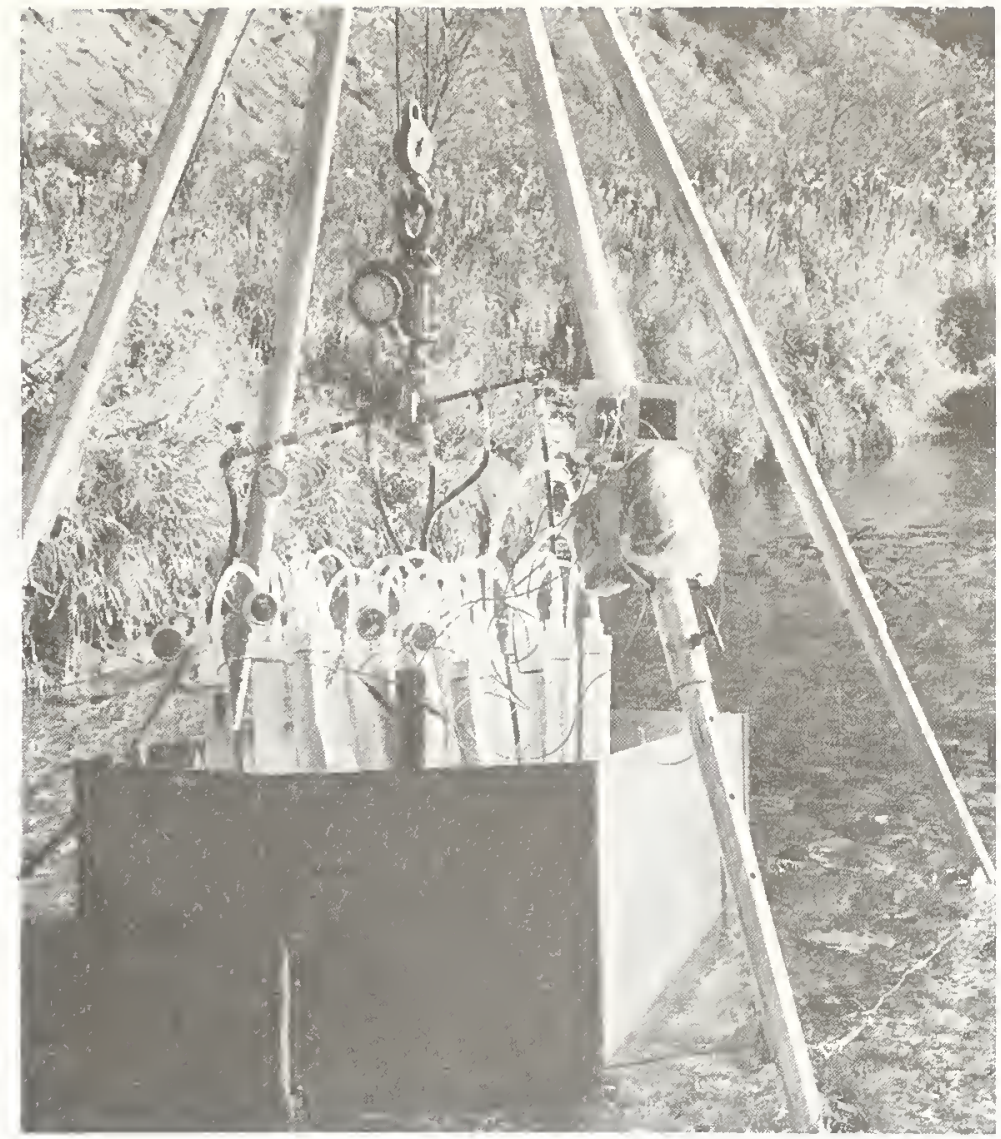

Figure 8.--Test setup showing hose connections and A-frame.

\section{Temperature Equipment}

A Digitec model 5900 digital thermometer and a six position Omega thermocouple switch are used to measure the temperature of the downstream probe in each row and of the two thermocouples placed in the substrate sample. The temperature of the downstream probes is needed to insure the $\mathrm{CO}_{2}$ was in liquid form.

\section{Sample Transportation}

An insulated boat was built to transport the sample. The floating capacity of the boat is $1,400 \mathrm{lb}(635 \mathrm{~kg})$ with a 4 -inch $(10 \mathrm{~cm})$ freeboard. An improvement needs to be made in transporting the sample by boat because of difficulties in supporting the sample in its original form and transporting it to the loading area.

\section{OPERATION OF EQUIPMENT}

Three basic cooling mediums were considered for freezing the sample: liquid nitrogen which is difficult to handle, mechanical refrigeration which is expensive, and liquid $\mathrm{CO}_{2}$ which was accepted as the medium for this method. The liquid $\mathrm{CO}_{2}$ method was tested twice in an artificial stream channel with good results and twice in a salmon spawning area. The first test in the spawning area showed we needed to stop most of the surface flow for good results. The second test showed freezing was easily accomplished by reducing the surface flows. 
The system was final tested by lifting a chinook salmon redd egg pocket in the Poverty Flat spawning area of the South Fork Salmon River in October 1978. A sample 30 by 54 by 17 inches deep $(0.76$ by 1.37 by $0.43 \mathrm{~m})$, weighing about $1,9901 \mathrm{~b}(900 \mathrm{~kg})$, was lifted from the redd. Twelve tanks containing $600 \mathrm{lb}(272 \mathrm{~kg})$ of $\mathrm{CO}_{2}$ were used to provide 75 minutes of freezing time which completely froze the sample at a river temperature of $37^{\circ} \mathrm{F}\left(3^{\circ} \mathrm{C}\right)$. The ratio of $\mathrm{CO}_{2}$ consumed to substrate lifted was about 0.35 $1 \mathrm{~b}$ to $1 \mathrm{lb}(0.34 \mathrm{~kg}$ to $1 \mathrm{~kg})$ dry sample. This value is better than the estimate of $0.37 \mathrm{lb} / \mathrm{lb}(0.37 \mathrm{~kg} \mathrm{CO} / \mathrm{kg})$.

The four corners of the sample area were marked with the outer corner probes (fig. 9 and 10). The ice anchors were driven into the sample and the wings spread so they were at least 9 inches $(23 \mathrm{~cm}$ ) below the channel surface. They were also angled inward to eliminate bending force during lifting of the sample.

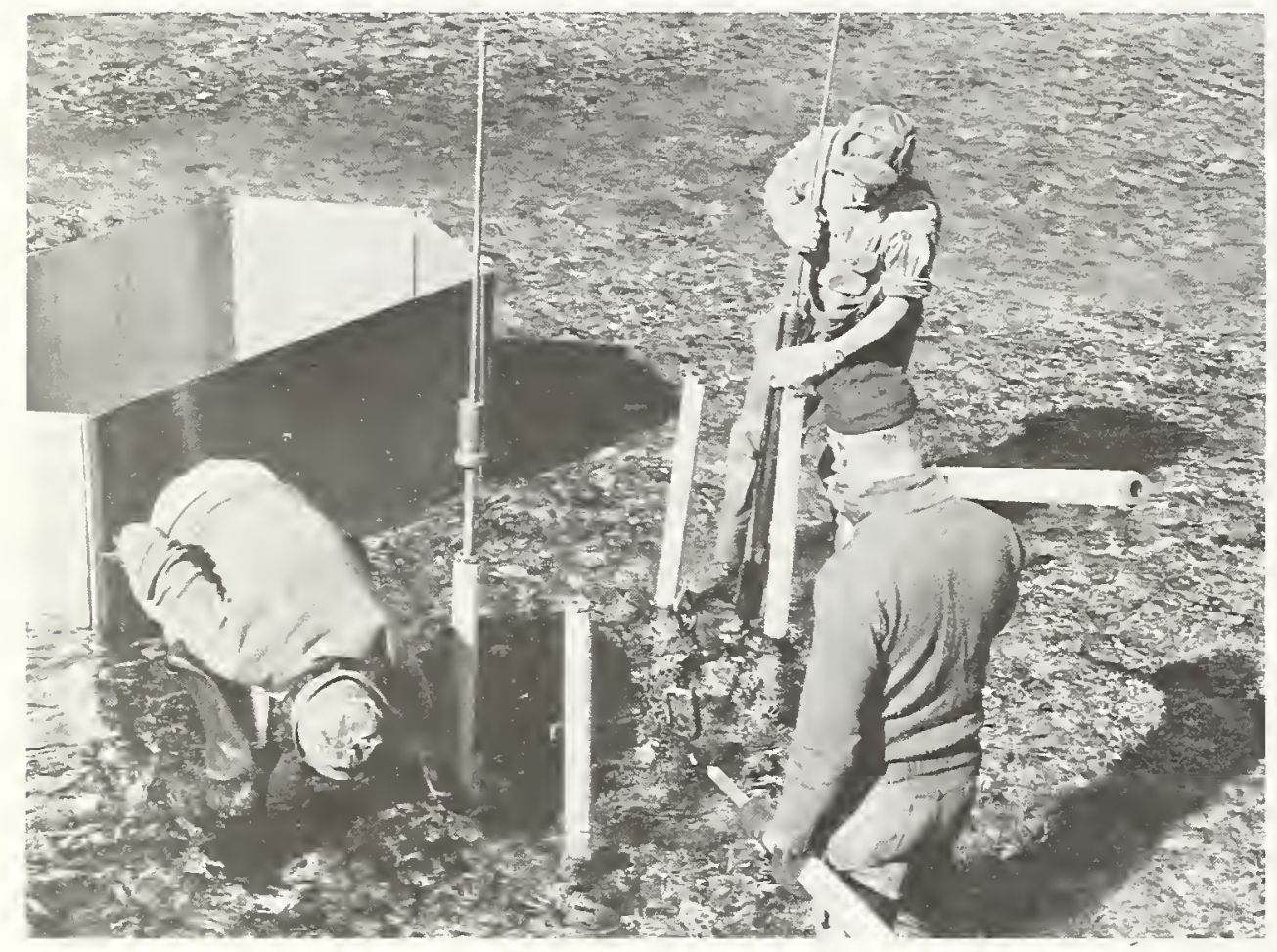

Figure 9.--Probes being driven into the chinook salmon redd.

\section{Probes and Caps}

The probes were driven into the streambed with a slide hammer (fig. 9) and two suffered minor damage. To avoid damage a hardened steel shaft can first be driven to the desired depth, withdrawn, and the probe placed in the remaining hole. The corner probes defined the 18 by 32 -inch $(0.45$ by $0.81 \mathrm{~m})$ sample. The remaining probes were placed within the rectangle at 6 -inch $(15.2 \mathrm{~cm})$ intervals to a depth of 12 inches $(30.4 \mathrm{~mm})$. During probe installation the $\mathrm{CO}_{2}$ tank frames were set up and the tanks connected together. Aluminum tanks were used which weighed $50 \mathrm{lb}(23 \mathrm{~kg})$ empty instead of steel tanks that weigh $100 \mathrm{lb}(45 \mathrm{~kg})$ empty. The tanks, hoses, and connections were checked for leaks by closing the valve on the end of the hose and opening one tank valve to apply pressure. The tank valve was then closed until ready to operate. Before installation of the probe caps, probes were checked with a dry dipstick for water that may have leaked in through cracks or tears.

The caps with throttle valves were placed on the four upstream probes and the caps with pressure gages and relief valves were placed on the four downstream probes. After the caps were in place, the plastic tubing was connected between the probes. The nylon tubing was pushed straight in the receiving couplet as far as it would go, carefully avoiding any kinks. The tubing connected the outlet on one probe to the inlet of the next downstream probe. The inlet connection was always next to the cap bolt retaining pin. 

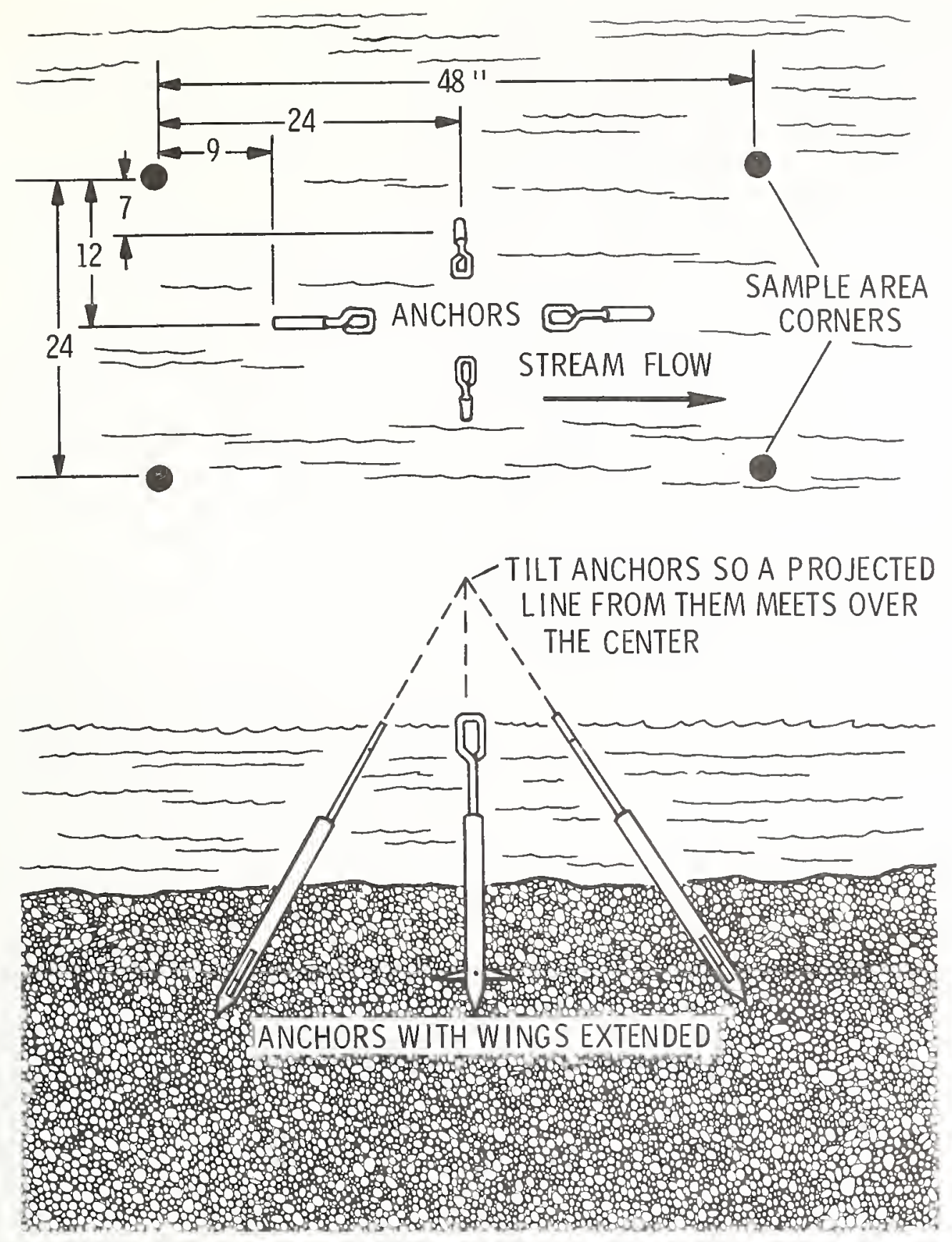

Figure 10.--Drawing of anchor location.

\section{Water Flow Shield, Lifting Hoist, and Instrumentation}

The water flow shield was placed around the probes to stop surface water circulation (fig. 11). Leaks into the sample area were indicated by water currents near the inside edge of the shield. A canvas was used to cover the upstream side of the shield for a tighter seal. The lifting hoist was then placed over the sample area.

The $\mathrm{CO}_{2}$ distribution manifold was connected to the probes and then to the $\mathrm{CO}_{2}$ tanks. $\mathrm{CO}_{2}$ was turned into each row of probes and leaks were located by looking for bubbles in the water around the probes. If leaks were found, the leaking probe was replaced. Small leaks will not cause the test to fail, but it slows ice formation around the probe.

The thermocouple meter was wrapped in a plastic bag to protect it from water. The thermocouple switch can be taped to the lifting frame near the throttle valves for easy access. The four downstream probe thermocouple probes were inserted in the streambed in one of the larger spaces between the probes and connected to the thermocouple 


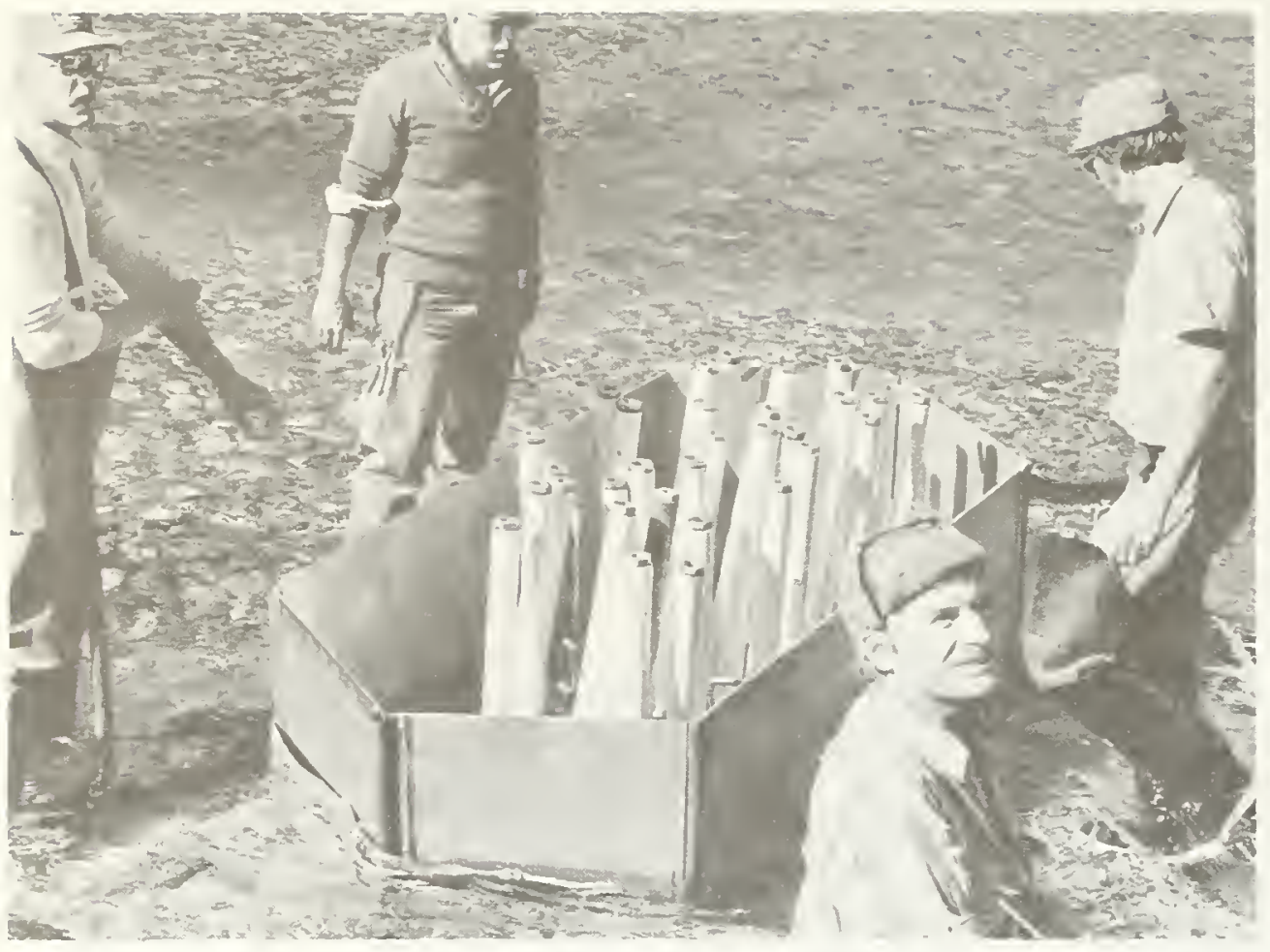

Figure 11.--Probes with cofferdam and canvas in place.

switch. The thermocouple temperatures should all record the same ambient stream temperature prior to the freezing operation. The boat for transporting the sample was anchored near the site.

\section{FREEZING PROCEDURE}

Gloves and goggles were worn by persons working in the immediate area during operation. The $\mathrm{CO}_{2}$ tanks were fully turned on with the main valve and throttle valves closed. The time was recorded upon opening each of the throttle valves. The first throttle valve was opened $2-1 / 2$ to 3 turns with immediate adjusting of the corresponding relief valve to maintain 65 to $70 \mathrm{psig}(0.448$ to $0.483 \mathrm{MPa})$ in the system. Above $5,000 \mathrm{ft}(1524 \mathrm{~m})$ mean sea level the gage pressuré should read at least 70 psig (0.483 $\mathrm{MPa})$. This operation was repeated on each of the rows.

The pressure gages and probe temperatures were checked to determine when the probes were full of liquid $\mathrm{CO}_{2}$. When the temperature registered $-26^{\circ} \mathrm{F}\left(-15^{\circ} \mathrm{C}\right)$, or 1 ess, the last probe had filled. The throttle valve was then turned to within $1 / 2$ to 1 turn from closed. If the temperature reached $-40^{\circ} \mathrm{F}\left(-40^{\circ} \mathrm{C}\right)$, or the gage started fluctuating rapidly, or dry ice escaped from the relief valve, the valve was turned off until the gage stopped fluctuating and then reopened $1 / 2$ to 1 turn while observing the probe: temperature.

The last probe in each row was kept between $-26^{\circ}$ and $-40^{\circ} \mathrm{F}\left(-15^{\circ}\right.$ to $\left.-40^{\circ} \mathrm{C}\right)$. We initially set the valve at 1 turn and then gradually closed it to $1 / 2$ turn near the end of the test. This generally provided the proper $\mathrm{CO}_{2}$ flow. The gages were watched closely and when rapid gage fluctuations occurred, the $\mathrm{CO}_{2}$ was reduced or turned off temporarily. The relief valves generally required periodic adjustment to maintain the operating pressure at 65 to $70 \mathrm{psig}(0.448$ to $0.483 \mathrm{MPa})$. The freezing rate of the sample was checked by the amount of ice forming around the probes where they enter the streambed and by monitoring the temperature probes in the substrate. 


\section{Problems}

Two minor problems occurred in our tests. An ice block in one probe limited the flow of $\mathrm{CO}_{2}$ through that row of probes instead of at the valve. A blocked probe can be detected in two ways. The relief valve next to the throttle will open and start blowing dry ice, or frost will melt from the probe caps ahead of the restriction. The flow of $\mathrm{CO}_{2}$ to the blocked row of probes was turned off and the probes emptied of $\mathrm{CO}_{2}$ by holding the relief valves open. The cap was removed from the suspected probe and the ice blockage removed. The cap was then replaced and the flow of $\mathrm{CO}_{2}$ restarted.

The second problem was an apparent restriction in the $\mathrm{CO}_{2}$ supply hose indicating empty supply tanks. This was easily checked by observing the pressure gage at both ends of the hose. Both should register about the same pressure with the gage closest to the sample recording a slightly lower temperature. The $\mathrm{CO}_{2}$ pressure during the test ranged from 500 to 700 psig $(0.689 \mathrm{MPa})$ depending on ambient air temperature.

\section{Shut Down Procedure}

Six hundred pounds $\left(272 \mathrm{~kg}\right.$ ) of $\mathrm{CO}_{2}$ liquid provided 70 to 80 minutes of operation. When the $\mathrm{CO}_{2}$ tanks became empty, there was a drop in pressure at both line gages. The substrate temperature at the probes began to slowly increase regardless of throttle valve setting. The system was then shut down and the various hoses and tubing disconnected and removed. The water shield was removed, a chain sling connected to the four ice anchors, and the sample lifted (fig. 12). It required 4,000 to 5,000 1b (1 814 to $2268 \mathrm{~kg}$ ) of lift force to break the sample loose. The sample was lifted high enough to get the boat under it and then it was lowered into the boat for transport to the shore (fig. 13). Tank valves were closed and the main valve opened to drain the lines prior to disassembling the equipment.

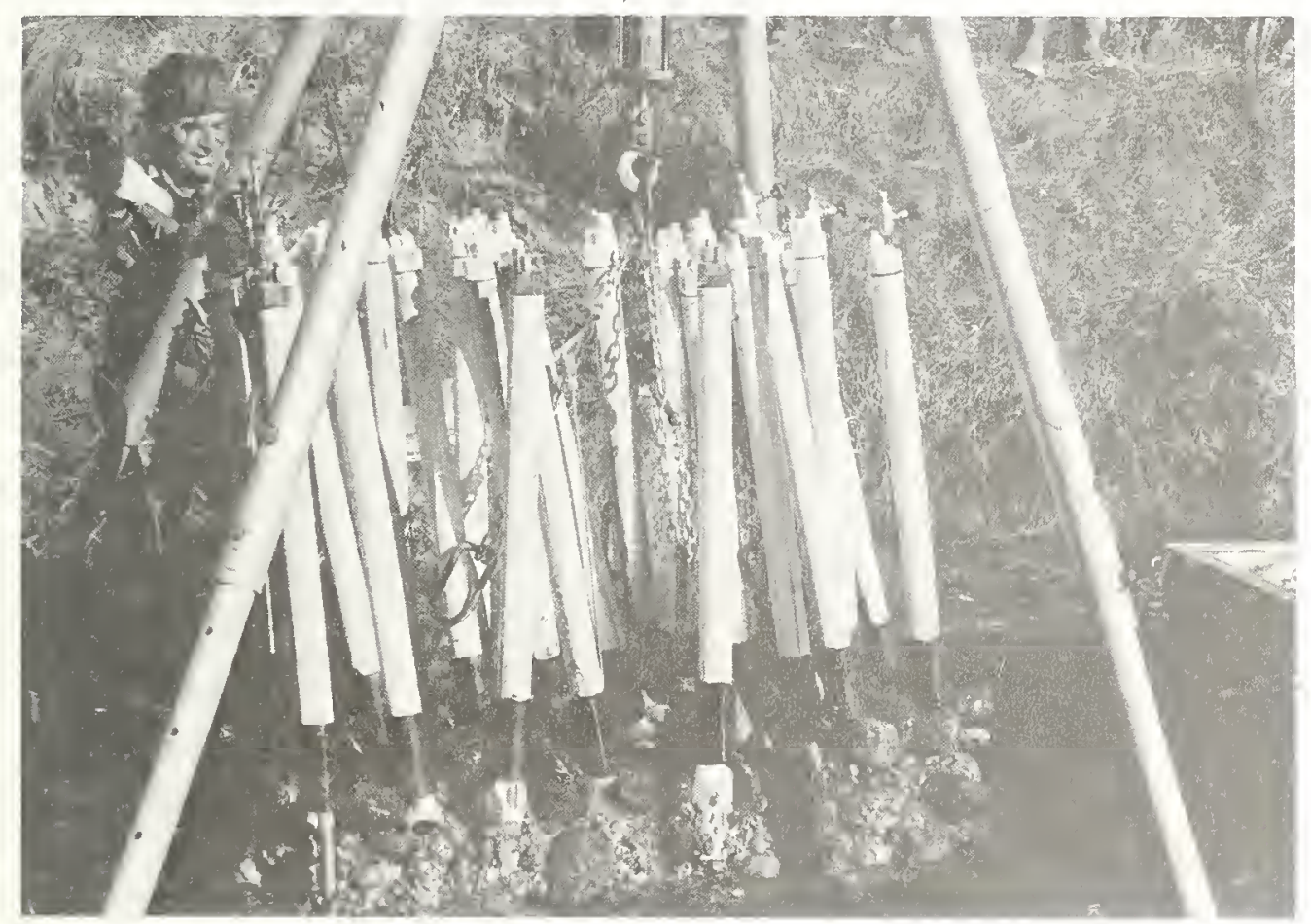

Figure 12.--Frozen sample being lifted.

The sample can be kept frozen by placing dry ice on top and around the sample. We had difficulties getting our egg pocket from the boat to the transporting trailer. Therefore, the top of the redd became unfrozen prior to transport. We transported the sample 145 miles to the $1 \mathrm{ab}$ and without the addition of ice, most of the redd remained frozen in the insulated carrying box upon arrival and even until the next morning when it was dissected. Dry ice would need to be added upon lifting the sample to get it to the place of analysis in its original condition. 


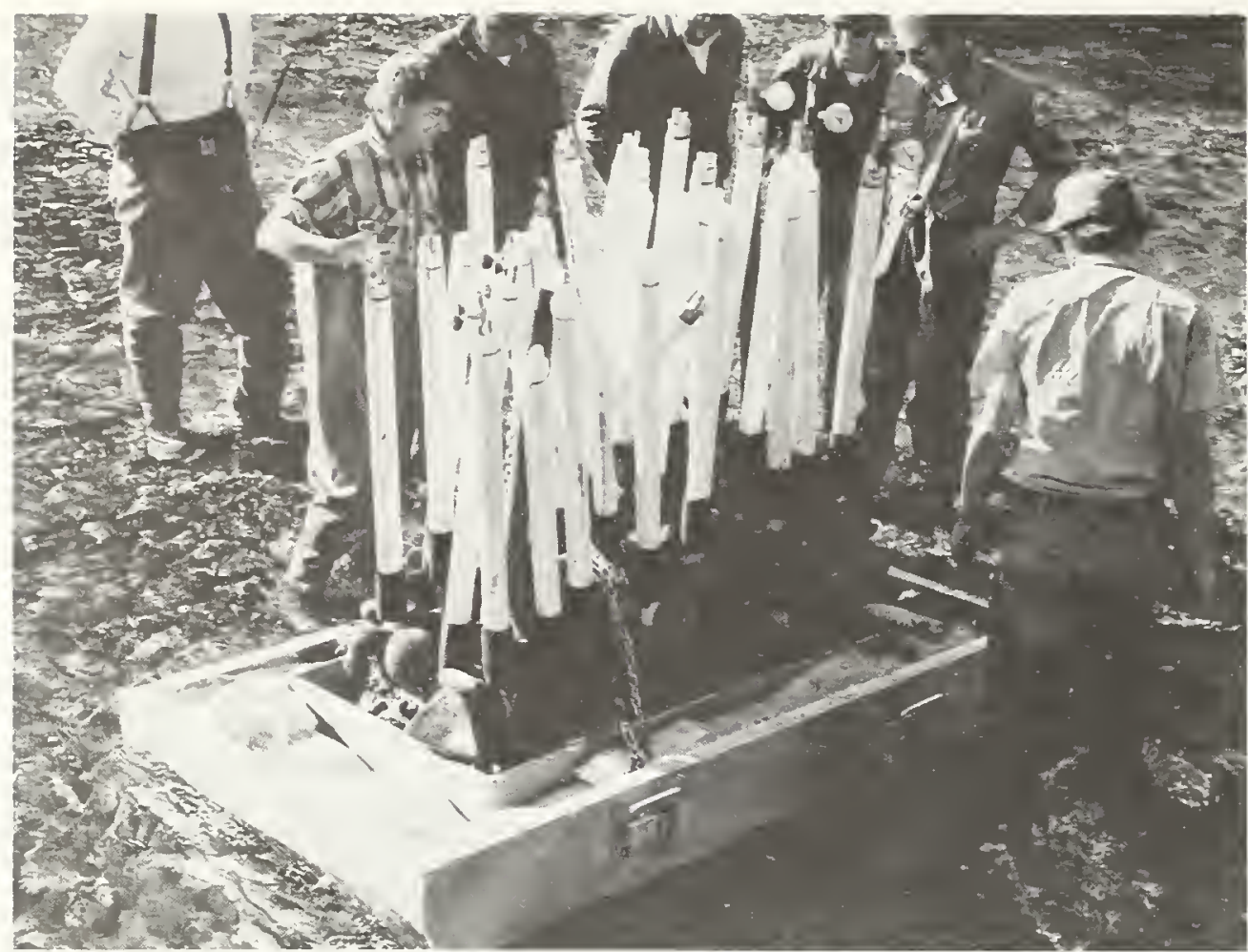

Figure 13.--Test sample loaded in boat.

\section{MAINTENANCE AND SAFETY}

The probes should be inspected before and after use for bends, cracks, and possible leaks. Each probe flange should be inspected to be sure it is still soldered to the probe. "Each probe cap should be inspected before and after use for torn 0-rings and other visible damage. After each use all filters should be cleaned. The throttle valves should be cleared by blowing air through the valve in a reverse direction.

All hoses should be checked for cracks in the outer cover, damaged coupling threads, and any inside obstructions before each use. Thermocouples need to be checked before and after each use for physical damage. The temperature indicator may need recalibration once each year. The batteries should be charged before each use. Prior to each use the relief valves next to the throttle valves should be checked with air pressure to be certain they open at $100 \mathrm{psig}(0.689 \mathrm{MPa})$. The lifting frame and winch should be inspected for loose bolts, kinks in tubes or plates, and fraying in the wire winch rope.

\section{DISCUSSION}

The method described is capable of freezing a complete redd, the redd egg pocket, or any portion of the redd. The individual sample size can be adjusted to provide a more optimum determination of egg location, of the number of embryos and alevins in the redd, of the timing of embryo development and fry emergence, the embryo and alevin survival rate, and sediment particle size distribution by both vertical and horizontal stratification. It will allow this type of analysis because the redd sample can be dissected in its original state using a dissecting grid system. The equipment will work under the conditions we have observed in salmon spawning areas if sufficient access is available.

The method has some of the same disadvantages that other freeze methods have. It can smash embryos and alevins as the probes are-being placed in the redd making it difficult to separate natural from artificial mortality, and it kills all the embryos and alevins in the sample. This can be very significant in streams having low runs of salmonids and could preclude the use of taking the complete redd pocket. When you 
analyze the number of samples required with the commonly used small core sampler, to meet statistical requirements it could also preclude their use in streams with low salmonid runs.

This method also has disadvantages that other methods do not. It requires the stoppage of most of the surface flows. However, this should probably be done in all freeze core sampling to prevent the bulbous samples that are often collected. The time required to take a sample is longer than the other methods. The equipment is more expensive (about $\$ 5,000$ to construct) and more difficult to transport to the study site (appendix B). All the equipment is hand-portable but there is more of it and the equipment takes more experience and expertise to operate.

Regardless of these disadvantages, there may be times when this method may provide the best results because it can reduce sample bias, it takes a more uniform sample, will collect more sample per unit of $\mathrm{CO}_{2}$ used, the individual sample size can be varied to meet analysis needs, and it offers an excellent opportunity to lift redds in their natural condition. Thus, these redds could be taken to the laboratory or artificial stream channel for additional study and analysis. The method can be reduced in complexity and size to meet small sample needs.

This method can help us better our understanding of the salmonid life cycle from the egg to the emergent embryo. It is a unique experience and an education to be able to dissect a redd egg pocket in its natural state. 


\section{PUBLICATIONS CITED}

Ashrae.

1973. Handbook of Fundamentals, Ch. 1, 7. Am. Soc. Heating, Refrigerating, and Air-Conditioning Eng., Inc.

Baumester, Theodore, and Lionel S. Marks.

1967. Standard Handbook for Mechanical Engineers. 7th ed. p. 4-10 to 4-22.

McGraw-Hill Co.

Lotspeich, Fred, and Barry Reid.

[In press.] A tri-tube freeze core procedure for sampling stream-gravel. Prog.

Fish Cult.

McNeil, W. J.

1964. A method of measuring mortality of pink salmon eggs and larvae. U.S.

Department of Interior, Fish and Wildl. Serv. Fish Bull. 63(3):575-588.

McNeil, W. J., and W. H. Ahnell.

1964. Success of pink salmon spawning relative to size of spawning bed materials.

U.S. Department of Interior, Fish and Wildl. Serv. Specific Sci. Rep.,

Fisheries No. 469, 15 p. Washington, D.C.

Platts, William S., and Walter F. Megahan.

1975. Time trends in riverbed sediment composition in a salmon and steelhead spawn-

ing area: South Fork Salmon River, Idaho. p. 229-239. Trans. 40th North Am. and

Nat1. Resour. Conf., Wild1. Manage. Inst., Washington, D.C.

Ringler, Neil H.

1970. Effects of logging on the spawning bed environment in two Oregon coastal

streams: 96 p. Oreg. State Univ., Corvallis.

Terzaphi, Karl, and Ralph Peck.

1948. Soil mechanics in engineering. p. 25-30. John Wiley and Sons, Inc., New York. Walkotten, William J.

1976. An improved technique for freeze sampling streambed sediments. USDA For. Serv.

Res. Note PNW-281, 11 p. Pac. Northwest For. and Range Exp. Stn., Portland, Oreg. 


\section{APPENDIX A}

\section{Equipment List and Suppliers}

Probe Cap Parts

Quantity

8

4

56

4

$100 \mathrm{ft}$

$32+$
Description

Inlet and outlet pressure relief valves (Nupro 6R-4M-50)

Inlet throttle valves (Whitney brass screwed bonnet, regulating type with 0.093-inch orifice 2RF4 1/4-inch national pipe taper female threads)

Tube fittings (Legris LF 3000 part No. 3115-60-14)

Outlet pressure gage ( 2 or 2.5 inch brass case 0 to 100 psig)

Nylon tubing between probes (Nylo-Hiflexible pressure tubing $3 / 8$ inch $0 . D$. 0.295 I.D. 700 psi rating, stock No. $5173 \mathrm{~K} 15$ )

0 -rings for probe caps ( $1 / 8$ by $13 / 16$ inch I.D. by $1-1 / 6$ inches O.D., Buna-N or hytrile)

Carbon Dioxide Tank Connections and Supply Hose

12

4

2

4

12

Cylinder connections (CGA-320 to $1 / 4-$ inch national pipe taper for $\mathrm{CO}_{2}$ )

Line filters (75 to 100 microns, screen type, pressure rating 1500 psi)

Main supply hose (50 ft 3/8-inch I.D. SAE 100R3 hydraulic hose 1,125 psi pressure rating, 3/8-inch national pipe taper male fittings each end)

Manifold to probe inlet hose (18 inches long 1/4-inch I.D. SAE 100R3, 1/4-inch national pipe taper male fittings each end)

Tank to tank hose (12 inches long, otherwise same as above)

Farm or heavy equipment supplier

Main shut-off valve (Whitney 1VM6-screwed bonnet valve $\mathrm{V}$-stem 0.250 -inch orifice 3/8-inch national pipe taper male)

Miscellaneous hydraulic swivel fitting, pipe fittings, etc.

Matheson

Bottled gas

suppliers

Farm or heavy equipment supplier

Farm or heavy equipment supplier

Automation Products

Farm or heavy equipment supplier 
Probes

Lower removable insulating hose (Cell-O-

McMaster Carr

Flex cold pipe covering $3 / 4$-inch thick, catalog No. 4463K68). This could be used for insulating the entire probe in place of the cast foam and PVC pipe.

Temperature Indicator and Thermocouple Assemblies

1

4

2

1

6
Digitec model 5900-1 TC temperature indicator for type $\mathrm{T}$ thermocouples $-152^{\circ}$ to $+400^{\circ} \mathrm{C}$ plus Digitec model 7010 carrying case $^{1}$

Downstream probe thermocouple assemblies (Omega model CPSS-18G 32 inches long)

Streambed thermocouple assemblies (Omega model CPSS-14G 32 inches long)

Switch 6 position and 6 position jack panel same panel (Omega No. STR 3-6 and Omega SJP1-06-6T)

Type $\mathrm{T}$ thermocouple wire, connectors and clamps to make up cable assemblies (wire, Omega No. PVC-COCO-032; connector Omega No. P-COCO-MF; clamps, Omega No. PCLM)
Topp. Engineer Sales

Omega Engineering Inc.

Omega Engineering Inc.

Omega Engineering Inc.

Omega Engineering Inc.

${ }^{1}$ There are several suppliers who make items equivalent to the above temperature indicators and thermocouples. Some can supply the indicators with channel switching built into the meter. 


\section{APPENDIX B}

\section{Cost of Equipment and $\mathrm{CO}_{2}$}

Item Cost of Probe Components ${ }^{1}$

Quantity

\section{8}

4

1

4

4

56

16

32

$7 \mathrm{ft}$

$140 \mathrm{ft}$

$140 \mathrm{ft}$
Description

Relief valves Nupro 6R-4M-50

Regulating valves Whitney 2RF4

Main shut-off valve Whitney IVMG

Pressure gages 0-100 psig

Line filters

Tube fittings Legris LF 3000 part No. 3115-60-14

Cell-0-Flex cold pipe insulation $6 \mathrm{ft}$ lengths

O-rings for probes

2 -inch brass hexagon rod

0.375 -inch O.D. by 25 -inch $\mathrm{I} . \mathrm{D}$. type $\mathrm{K}$ rigid copper tube

1-inch nominal type $\mathrm{M}$ rigid copper water pipe

Miscellaneous steel for retainer bolts and probe points

Estimated labor for 32 probes, 64 h @ $\$ 20.00$

Estimated cost per probe $\$ 67.00$
Total Cost

$\$ 80.00$

100.00

12.00

36.00

36.00

110.00

122.00

6.40

174.00

52.00

126.00

$\frac{10.00}{\$ 864.00}$

$\frac{1280.00}{\$ 2144.00}$

Item Cost of Hoses, Fittings, Tank Supports, Etc.

\section{Quantity}

4

12

12

\section{Description}

$50 \mathrm{ft}$ high pressure hoses 0.375 inch I.D.

18-inch high pressure hoses 0.25 inch I.D.

12-inch high pressure hoses 0.25 inch I.D.

$\mathrm{CO}_{2}$ tank connectors

Miscellaneous swivel, tee elbows and nipples

Labor and materials to build two $\mathrm{CO}_{2}$ tank

support frames
Total Cost

$\$ 116.00$

20.00

63.00

54.00

40.00

$\frac{150.00}{\$ 443.00}$

${ }^{1}$ The above prices are figured using Cell-0-Flex insulation for the whole probe in place of PVC pipe and insulating foam. The PVC insulating foam would add about $\$ 7.00$ to each probe. 
1

4

2

1

1

4

1

Thermocouple meter and case

0.125 -inch by 32 -inch type $\mathrm{T}$ thermocouples

0.25 -inch by 32 -inch type $T$ thermocouples

Thermocouple switch and jack panel

Thermocouple lead cables

Probe drivers

Flow shield materials and labor

Anchors materials and labor

A-frame materials

A-frame labor

Total

$\$ 385.00$

140.00

66.00

119.00

90.00

$\$ 764.00$

$\$ 100.00$

200.00

200.00

620.00

700.00

$\$ 1820.00$

Total misc. items
$\$ 2144.00$

443.00

764.00

1820.00

$\$ 5173.00$

TOTAL

${ }^{2}$ Extra probes, 0-rings, fittings, tools, etc., should be considered when putting together a system. These would add about $\$ 300.00$ to the total cost. $\mathrm{CO}_{2}$ would be about $\$ 17.00$ per 50 pound tank or $\$ 204.00$ per test. 
Platts, William S., and Vance E. Penton.

1980. A new freezing technique for sampling salmonid redds. USDA For. Serv. Res. Pap. INT-248, 22 p. Intermt. For. and Range Exp. Stn., Ogden, Utah 84401.

This report describes a new multiprobe freeze method for determining salmonid redd sediment particle size distribution. This method will collect salmonid eggs and alevins in the redd at any stage of development, any air or water temperature, any stream depth, and determine their horizontal and vertical location. This method allows larger size samples to be collected which can help improve understanding of embryo and alevin survival rates and causes of their mortality. A complete step by step description of the methodology is given with a listing of parts, materials, and suppliers.

KEYWORDS: Salmonid, salmon, sediments, freeze method, redd, channel, stream, carbon dioxide, freeze core sampling.

Platts, William S., and Vance E. Penton.

1980. A new freezing technique for sampling salmonid redas. USDA For. Serv. Res. Pap. INT-248, 22 p. Intermt. For. and Range Exp. Stn., Ogden, Utah 84401.

This report describes a new multiprobe freeze method for determining salmonid redd sediment particle size distribution. This method will collect salmonid eggs and alevins in the redd at any stage of development, any air or water temperature, any stream depth, and determine their horizontal and vertical location. This method allows larger size samples to be collected which can help improve understanding of embryo and alevin survival rates and causes of their mortality. A complete step by step description of the methodology is given with a listing of parts, materials, and suppliers.

KEYWORDS: Salmonid, salmon, sediments, freeze method, redd, channel, stream, carbon dioxide, freeze core sampling. 

The Intermountain Station, headquartered in Ogden, Utah, is one of eight regional experiment stations charged with providing scientific knowledge to help resource managers meet human needs and protect forest and range ecosystems.

The Intermountain Station includes the States of Montana, Idaho, Utah, Nevada, and western Wyoming. About 231 million acres, or 85 percent, of the land area in the Station territory are classified as forest and rangeland. These lands include grasslands, deserts, shrublands, alpine areas, and well-stocked forests. They supply fiber for forest industries; minerals for energy and industrial development; and water for domestic and industrial consumption. They also provide recreation opportunities for millions of visitors each year.

Field programs and research work units of the Station are maintained in:

Boise, Idaho

Bozeman, Montana (in cooperation with Montana State University)

Logan, Utah (in cooperation with Utah State University)

Missoula, Montana (in cooperation with the University of Montana)

Moscow, Idaho (in cooperation with the University of Idaho)

Provo, Utah (in cooperation with Brigham Young University)

Reno, Nevada (in cooperation with the University of Nevada)

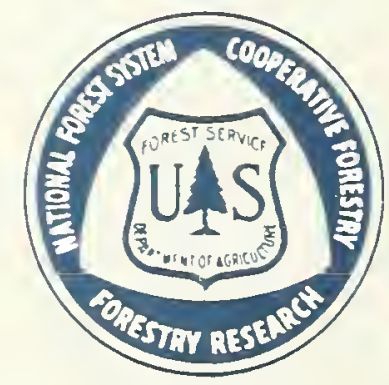

